\title{
PCR PRIMERS FOR THE AMPLIFICATION OF MITOCHONDRIAL SMALL SUBUNIT RIBOSOMAL DNA OF LICHEN-FORMING ASCOMYCETES
}

\author{
Stefan ZOLLER, * Christoph SCHEIDEGGER` and \\ Christoph SPERISEN*
}

\begin{abstract}
Four primers for the amplification of mitochondrial DNA of lichenforming ascomycetes are presented. The primers match the conserved regions U2, U4, and U6, respectively, of mitochondrial small subunit (SSU) ribosomal DNA (rDNA). Polymerase chain reaction using different combinations of the primers produced single amplification products from DNA of eight lichen-forming fungal species but did not amplify DNA of two axenic cultured algal species. The amplification product obtained from Lobaria pulmonaria was sequenced and the 894-bp sequence was compared with the mitochondrial SSU rDNA sequence of Podospora anserina. The two sequences revealed more than $76 \%$ identity in the conserved regions U3 to U5 demonstrating that we amplified mitochondrial DNA. The primers matching U2 and U6 yielded amplification products of $800-1000 \mathrm{bp}$ depending on the species examined. The variation observed suggests that mitochondrial SSU rDNA may be useful for phylogenetic analyses of lichen-forming ascomycetes.

(C) 1999 The British Lichen Society
\end{abstract}

\section{Introduction}

Analysis of nuclear ribosomal DNA (rDNA) has become an important tool in molecular studies of lichens. These studies have used rDNA to provide insight into the origin of lichens (Gargas et al. 1995), phylogenetic relationships (Lutzoni \& Vilgalys 1995; Tehler 1995), and population structures (DePriest 1993). Application of mitochondrial rDNA for lichen studies has not been described although mitochondrial rDNA of fungal species often reveals high levels of nucleotide substitutions and length mutations (Hibbett $\&$ Donoghue 1995; Gryta et al. 1997; Bruns et al. 1998; Gonzales \& Labarere 1998; Johnson 1999). In the basidiomycete order Boletales the variation of mitochondrial rRNA genes was even higher than that of nuclear rRNA genes (Bruns \& Szaro 1992).

In this study, we present primers for the amplification of mitochondrial small subunit (SSU) rDNA of lichen-forming fungi. The primers match the universal regions $\mathrm{U} 2, \mathrm{U} 4$ and $\mathrm{U} 6$, respectively. These regions are part of eight universally conserved regions that form the minimal core secondary structure of mitochondrial SSU rRNA (Gray et al. 1984; Schnare et al. 1986; Cummings et al. 1989). We show that the novel primers produce amplification

${ }^{\star}$ Swiss Federal Institute for Forest, Snow and Landscape Research, Zürcherstrasse 111, CH-8903 Birmensdorf, Switzerland. e-mail: stefan.zoller@wsl.ch 
TABLE 1. Primer sequences for amplification of mitochondrial SSU rDNA

\begin{tabular}{llll}
\hline Primer & Primer sequence & Forward/reverse & $\begin{array}{c}\text { Homologous } \\
\text { to U region }\end{array}$ \\
\hline mrSSU1 & 5'-AGCAGTGAGGAATATTGGTC-3' & Forward & U2 \\
mrSSU2 & 5'-CTGACGTTGAAGGACGAAGG-3' & Forward & U4 \\
mrSSU2R & 5'-CCTTCGTCCTTCAACGTCAG-3' & Reverse & U4 \\
mrSSU3R & 5'-ATGTGGCACGTCTATAGCCC-3' & Reverse & U6 \\
\hline
\end{tabular}

products from a broad range of lichen-forming ascomycetes and demonstrate that the amplification products reveal length differences among different species.

\section{Materials and Methods}

\section{Lichen and algal material}

The lichen species investigated were collected in Switzerland: Lobaria pulmonaria and Peltigera praetextata in Vordernwald, Canton of Aargau (co-ordinates $47^{\circ} 17 \pm 20^{\prime \prime} \mathrm{N}, 7^{\circ} 52 \pm 30^{\prime \prime} \mathrm{E}$ ); Lecanora allophana and Cladonia digitata in Gurnigel, Canton of Bern $\left(46^{\circ} 45 \pm 00^{\prime \prime} \mathrm{N}, 7^{\circ} 26 \pm\right.$ $\left.20^{\prime \prime} \mathrm{E}\right)$; Leptogium satuminum and Graphis scripta in Wägital, Canton of Schwyz $\left(47^{\circ} 04 \pm 00^{\prime \prime} \mathrm{N}\right.$, $8^{\circ} 54 \pm 40^{\prime \prime}$ E); Parmelia pastillifera and Parmelia sulcata in Bondo, Canton of Graubünden $\left(46^{\circ} 20 \pm 00^{\prime \prime} \mathrm{N}, 9^{\circ} 32 \pm 00^{\prime \prime} \mathrm{E}\right)$.

The algae Trebouxia species and Dictyochloropsis reticulata, the photobiont of $L$. pulmonaria, were isolated using the procedure developed by Yamamoto (1987) and cultured on Bold's Basal Medium BBM (Bischoff \& Bold 1963).

\section{Extraction of total DNA}

Total DNA of lichens was extracted as described by Ziegenhagen et al. (1993) and purified using the QIAamp DNA Blood Mini Kit (QIAGEN). Air-dried thallus pieces (up to $70 \mathrm{mg}$ ) were cleaned by hand, transferred into a $2-\mathrm{ml}$ precooled microfuge tube containing an agate ball $(7 \mathrm{~mm}$ in diameter), and ground to fine powder in a shaking mill (Micro-Dismembrator II, Braun) for $2 \mathrm{~min}$ at full speed. The powder was dispersed in $350 \mu \mathrm{l}$ of extraction buffer [ $100 \mathrm{mM}$ sodium acetate $\mathrm{pH} 5 \cdot 5,50 \mathrm{mM}$ EDTA, $500 \mathrm{mM} \mathrm{NaCl}, 2 \%$ (w/v) polyvinyl pyrrolidone, $1.4 \%(\mathrm{w} / \mathrm{v}$ ) sodium dodecyl sulphate supplemented with $0.5 \%(\mathrm{w} / \mathrm{v})$ sodium bisulphite], incubated at $65^{\circ} \mathrm{C}$ for at least $20 \mathrm{~min}$, and centrifuged for $15 \mathrm{~min}$ at $20000 \mathrm{~g}$. The supernatant $(c .300 \mu \mathrm{l})$ was transferred to a new $1.5-\mathrm{ml}$ tube and $300 \mu \mathrm{l}$ of AL buffer (provided with the kit) was added. The mixture was thoroughly shaken and incubated at $70^{\circ} \mathrm{C}$ for $10 \mathrm{~min}$. Three hundred microlitres of absolute ethanol were added and the mixture was transferred onto a spin column placed on a 2-ml collection tube (provided with the kit) and centrifuged for $1 \mathrm{~min}$ at $6800 \mathrm{~g}$. The column was washed by addition of $400 \mu \mathrm{l}$ of AW washing buffer (provided with the kit) and centrifugation for $1 \mathrm{~min}$ at $6800 \mathrm{~g}$. The washing step was repeated with a final centrifugation for $1 \mathrm{~min}$ at $20000 \mathrm{~g}$. The spin column was placed onto a new $1.5 \mathrm{ml}$ microfuge tube and incubated for $10 \mathrm{~min}$ at $70^{\circ} \mathrm{C}$ to dry the membrane. DNA was eluted by addition of $300 \mu \mathrm{TE}(1 \mathrm{mM}$ EDTA, $10 \mathrm{mM}$ Tris- $\mathrm{HCl}$ $\mathrm{pH} 9.0$, preheated to $70^{\circ} \mathrm{C}$ ), incubation for $5 \mathrm{~min}$ at $70^{\circ} \mathrm{C}$ in an oven, and centrifugation for $1 \mathrm{~min}$ each at $6800 \mathrm{~g}$ and $20000 \mathrm{~g}$. Finally, $5 \mu \mathrm{l}$ RNAse $\mathrm{A}\left(10 \mathrm{mg} \mathrm{ml}^{-1}\right)$ was added to each sample.

\section{Primer construction and PCR}

Four primers for amplification of fungal mitochondrial SSU rDNA were designed (Table 1). The primer sequences were derived from conserved regions among the ascomycetes Neurospora crassa (GenBank accession number: J05254), Aspergillus terricola (U29212), Trichophyton rubrum (X88896), Beauveria bassiana (U91338), Petromyces albertensis (U29229), and Podospora anserina (X14734). A BLAST search on the GenBank database was performed to verify specificity to 


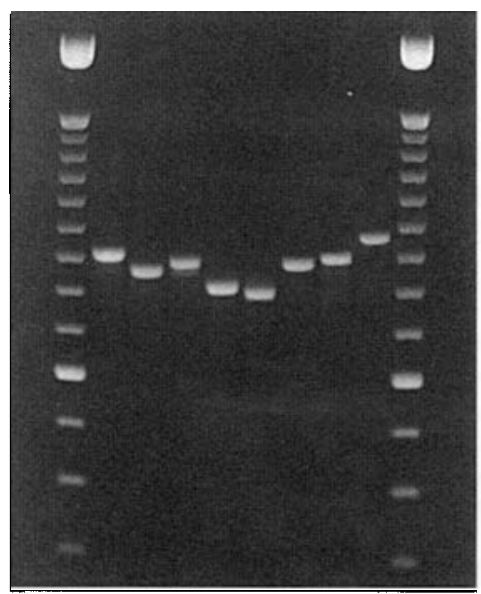

FIG. 1. Agarose-gel electrophoresis of PCR products obtained with primers matching the conserved regions U2 and U6 of the mitochondrial SSU rDNA. Lanes 1 and 10: 100-bp DNA ladder with brighter $600-\mathrm{bp}$ band (GiBCoBRL). Lanes 2-9 contain $5 \mu$ l of PCR product of the following taxa: Cladonia digitata (2); Peltigera praetextata (3), Graphis scripta (4), Lecanora allophana (5), Leptogium saturninum (6), Lobaria pulmonaria (7), Parmelia pastillifera (8), and Parmelia sulcata (9).

fungal sequences. Amplification of fungal and algal DNAs was performed in $50 \mu \mathrm{l}$ reaction volumes $\left[1 \times\right.$ PCR buffer (GiBcoBRL), $1 \mathrm{mM}$ dNTPs, $2 \mathrm{mM} \mathrm{MgCl}_{2}, 2 \mu \mathrm{M}$ of each primer, 2.5 U Taq DNA polymerase (GIBCoBRL), $2 \mu \mathrm{l}$ DNA extract] in a thermal cycler (PTC-100, MJ RESEARCH, INC.) using a standard cycling protocol: denaturation at $94^{\circ} \mathrm{C}$ for $3 \mathrm{~min} ; 35$ cycles with $94^{\circ} \mathrm{C}$ denaturation for $1 \mathrm{~min}$, annealing at $52^{\circ} \mathrm{C}$ for $1 \mathrm{~min}$, and extension at $72^{\circ}$ for $1 \mathrm{~min}$; followed by a final extension at $72^{\circ} \mathrm{C}$ for $7 \mathrm{~min}$. PCR products were analysed on $2 \% \mathrm{TBE}$-agarose gels. The two primers MS1 and MS2 (White et al. 1990) were tested using the same PCR procedure with DNA of L. pulmonaria.

\section{Sequence analysis}

The PCR-product of $L$. pulmonaria was ethanol precipitated and sequenced with the Applied Biosystems Dye Terminator Cycle Sequencing Ready Reaction Kit (ABI). Nucleotide base detection was performed on an Applied Biosystems 310 genetic analyser. Cycle sequencing was carried out with the PCR primers. Sequences were assembled using Sequencher 3.0 (Gene Codes Corporation) and manually adjusted. The alignment of $L$. pulmonaria and $P$. anserina sequences was done with GAP of the GCG 9.1 software package (Genetics Computer Group) by using a gap creation penalty of 5.00 and a gap extension penalty of 0.30 . An unambiguous alignment of the two sequences was not possible. We did not do any visual adjustments although in several regions more matches could have been obtained.

\section{Results and Discussion}

The primers MS1 and MS2, previously described for the amplification of fungal mitochondrial small subunit rDNA (White et al. 1990) did not amplify DNA of Lobaria pulmonaria. However, the primers we designed on the basis of conserved ascomycete sequences yielded single amplification products from all eight lichen-forming fungal species examined. The primers did not amplify DNA from axenic cultures from the two algae Trebouxia species and Dictyochloropsis reticulata, the photobiont of $L$. pulmonaria. Moreover, a GenBank 


\begin{tabular}{|c|c|c|}
\hline $\begin{array}{l}\text { P. anserina } \\
\text { L. pulmonaria }\end{array}$ & 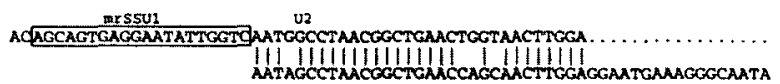 & 70 \\
\hline$P$. anserina & 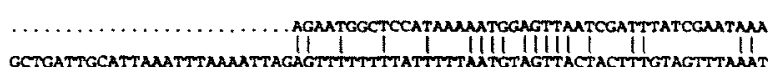 & 140 \\
\hline $\begin{array}{l}\text { L. pulmonaria } \\
\text { P. anserina } \\
\text { L. pulmonaria }\end{array}$ & 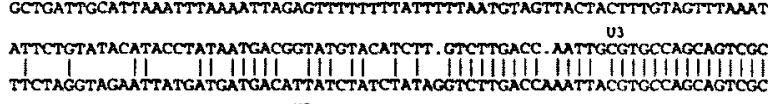 & 210 \\
\hline $\begin{array}{l}\text { P. anserina } \\
\text { L. pulmonaria }\end{array}$ & 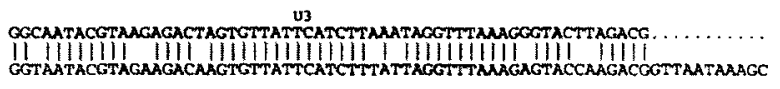 & 280 \\
\hline $\begin{array}{l}\text { P. anserina } \\
\text { L. pulmonaria }\end{array}$ & 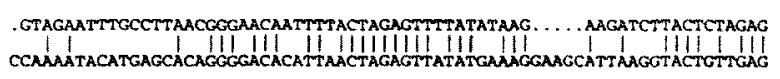 & 350 \\
\hline $\begin{array}{l}\text { P. anserina } \\
\text { L. pulmonaria }\end{array}$ & 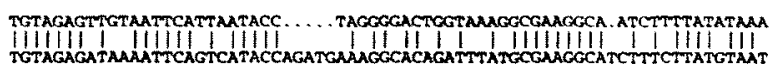 & 420 \\
\hline $\begin{array}{l}\text { P. anserina } \\
\text { L. pulmonaria }\end{array}$ & 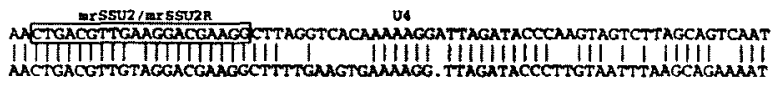 & 490 \\
\hline $\begin{array}{l}\text { P. anserina } \\
\text { L. pulmonaria }\end{array}$ & 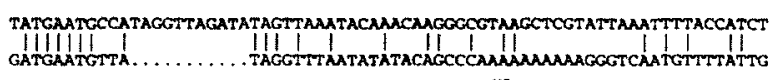 & 560 \\
\hline $\begin{array}{l}\text { P. anserina } \\
\text { L. pulmonaria }\end{array}$ & 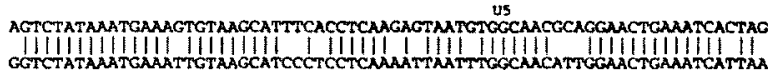 & 630 \\
\hline $\begin{array}{l}\text { P. anserina } \\
\text { L. pulmonaria }\end{array}$ & 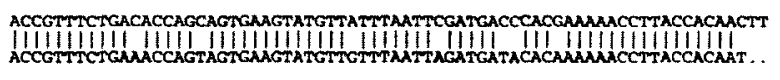 & 700 \\
\hline $\begin{array}{l}\text { P. anserina } \\
\text { L. pulmonaria }\end{array}$ & $\begin{array}{l}\text { GAATATAAUMAATGCTATCTACTACCATCACTTATTTAAAGGTAGCGGCGCGGGGCCGCGAAAGCTCCT } \\
\ldots \ldots \ldots \ldots \ldots \ldots \ldots \ldots \ldots \ldots \ldots \ldots \ldots \ldots \ldots \ldots \ldots \ldots \ldots \ldots \ldots \ldots \ldots\end{array}$ & 770 \\
\hline $\begin{array}{l}\text { P. anserina } \\
\text { L. pulmonaria }\end{array}$ & CСТCGCTCTAAATTTAAGTGTTAGGCGCAAGCTCTANGA & 840 \\
\hline $\begin{array}{l}\text { P. anserina } \\
\text { L. pulmonaria }\end{array}$ & 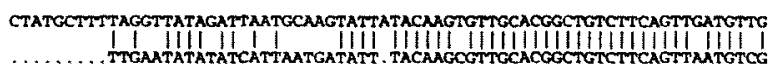 & 910 \\
\hline $\begin{array}{l}\text { P. anserina } \\
\text { L. pulmonaria }\end{array}$ & 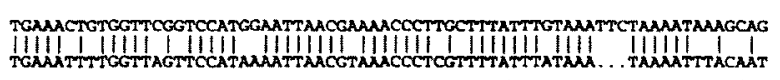 & 980 \\
\hline $\begin{array}{l}\text { P. anserina } \\
\text { L. pulmonaria }\end{array}$ & 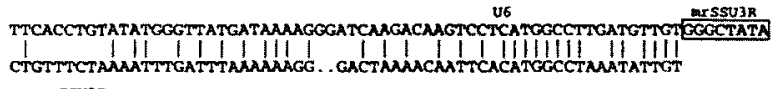 & 1050 \\
\hline P. anserina & BACGTSCCCACAT]GTACCTAAACAMAGAG 1078 & \\
\hline
\end{tabular}

FIG. 2. Sequence comparison of mitochondrial SSU rDNA of Podospora anserina (GenBank Accession X14734) and Lobaria pulmonaria. The mitochondrial sequence of $L$. pulmonaria was deposited in the GenBank database (Accession Nr. AF069541). U2 to U6 denote the universally conserved regions and are shaded. Primer sequences are given in boxes.

search did not reveal any significant similarities between the primer and algal sequences.

Primers matching the universally conserved regions U2 and U6 (see Table 1) produced single amplification products of approximately 800 $1000 \mathrm{bp}$ depending on the species examined (Fig. 1). Primers homologous to $\mathrm{U} 2$ and $\mathrm{U} 4$, and $\mathrm{U} 4$ and $\mathrm{U} 6$, respectively, resulted in amplification products of $400-500 \mathrm{bp}$. Five of the seven species could clearly be distinguished based on PCR-fragment-length differences. The two species Graphis scripta and $L$. pulmonaria gave similar fragment lengths.

The amplification product of L. pulmonaria was sequenced and the 894-bp sequence was compared with the mitochondrial SSU rDNA sequence of Podospora anserina (Cummings et al. 1989). The two sequences revealed $76 \%$ 
to $89 \%$ identity in the regions $\mathrm{U} 3$ to $\mathrm{U} 5$ demonstrating that mitochondrial DNA was amplified (Fig. 2). From U2 and U6, only segments were amplified revealing $88 \%$ and $71 \%$ identity, respectively. The sequences between the conserved regions showed considerable length differences. To align these sequences, a total of nine gaps of 1 to $131 \mathrm{bp}$ length had to be introduced (Fig. 2). Parts of these regions could not be aligned unambiguously.

Our findings are consistent with results obtained from basidiomycetes, often showing species-specific length mutations in mitochondrial rDNA (Bruns \& Szaro 1992; Hibbett \& Donoghue 1995; Bruns et al. 1998; Gonzales \& Labarere 1998). This variation together with nucleotide substitutions has been proved to be useful for phylogenetic studies. By analogy with the basidiomycetes the findings of this study shows promise that mitochondrial SSU rDNA may also be useful for studying the phylogeny of lichenforming ascomycetes. Mitochondrial rDNA may be valuable for phylogenetic analyses for several reasons. First, mitochondrial rDNA appears to reveal high rates of nucleotide substitutions in many fungal species, in the order Boletales higher than that observed in its nuclear counterpart (Bruns \& Szaro 1992). A reduced constraint on mitochondrial rRNA has been proposed as an important factor contributing to the high rates of nucleotide substitutions observed although increased mutation rates could not be excluded. Second, mitochondrial DNA is uniparentally inherited in most ascomycetes studied so far (Röhr et al. 1999). Variation uniparentally inherited is more prone to genetic drift and founder events than variation of nuclear DNA, both resulting in reduced diversity and higher rates of molecular divergence (Moritz et al. 1987). Finally, concerted evolution might be rather different in mitochondrial rDNA because the mitochondrial genomes are partitioned into many mitochondria and are separated mitotically. In summary, mitochondrial rDNA appears to show different modes and rates of evolution than nuclear rDNA and may thus represent an additional marker to the widely used nuclear rDNA.

We thank Beat Frey for providing the axenic cultures of algae, Urs Büchler, Kurt Eichenberger and Gábor Mátyás for technical assistance, and François Lutzoni (The Field Museum, Chicago) for his help with primer construction.

\section{REFERENCES}

Bischoff, H. W. \& Bold, H. C. (1963) Physiological studies: IV. Some soil algae from enchanted rock and related algal species. University of Texas Publications No. 6318, Physiological Studies 4: $1-95$.

Bruns, T. D. \& Szaro, T. M. (1992) Rate and mode differences between nuclear and mitochondrial small-subunit rRNA genes in mushrooms. Molecular Biology and Evolution 9: 836-855.

Bruns, T. D., Szaro, T. M., Gardes, M., Cullings, K. W., Pan, J. J., Taylor, D. L., Horton, T. R., Kretzer, A., Garbelotto, M. \& Li, Y. (1998) A sequence database for the identification of ectomycorrhizal basidiomycetes by phylogenetic analysis. Molecular Ecology 7: 257-272.

Cummings, D. J., Domenico, J. M., Nelson, J. \& Sogin, M. L. (1989) DNA sequence, structure and phylogenetic relationships of the small subunit rRNA coding region of mitochondrial DNA from Podospora anserina. Fournal of Molecular Evolution 28: 232-241.

DePriest, P. T. (1993) Small subunit rDNA variation in a population of lichen fungi due to optional group I introns. Gene 134: 67-71.

Gargas, A., DePriest, P. T., Grube, M. \& Tehler, A. (1995) Multiple origins of lichen symbioses in fungi suggested by SSU rDNA phylogeny. Science 268: 1492-1495. 
Gonzales, P. \& Labarere, J. (1998) Sequence and secondary structure of the mitochondrial small-subunit rRNA V4, V6, and V9 domains reveal highly species-specific variations within the genus Agrocybe. Applied and Environmental Microbiology 64: 4149-4160.

Gray, M. W., Sankoff, D. \& Cedergren, R. J. (1984) On the evolutionary descent of organisms and organelles: a global phylogeny based on a highly conserved structural core in small subunit ribosomal RNA. Nucleic Acids Research 12: 5837-5852.

Gryta, H., Debaud, J. C., Effosse, A., Gay, G. \& Marmeisse, R. (1997) Fine-scale structure of populations of the ectomycorrhizal fungus Hebeloma cylindrosporum in coastal sand dune forest ecosystems. Molecular Ecology 6: 353-364.

Hibbett, D. S. \& Donoghue, M. J. (1995) Progress toward a phylogenetic classification of the Polyporaceae through parsimony analysis of mitochondrial ribosomal DNA sequences. Canadian fournal of Botany 73(Suppl. 1): 853-861.

Johnson, J. (1999) Phylogenetic relationships within Lepiota sensu lato based on morphological and molecular data. Mycologia 91: 443-458.

Lutzoni, F. \& Vilgalys, R. (1995) Omphalina (Basidiomycota, Agaricales) as a model system for the study of coevolution in lichens. Cryptogamic Botany 5: 71-81.

Moritz, C., Dowling, T. E. \& Brown, W. M. (1987) Evolution of animal mitochondrial DNA: relevance for population biology and systematics. Annual Review of Ecology and Systematics 18: $269-292$.

Röhr, H., Kües, U. \& Stahl, U. (1999) Recombination: Organelle DNA of plants and fungi: Inheritance and recombination. In Progress in Botany 60 (K. Esser, J. W. Dadereit, U. Lüttge \& M. Runge, eds): Berlin: Springer.

Schnare, M. N., Heinonen, T. Y. K., Young, P. G. \& Gray, M. W. (1986) A discontinuous small subunit ribosomal RNA in Tetrahymena pyriformis mitochondria. Fournal of Biological Chemistry 261: 5187-5193.

Tehler, A. (1995) Arthoniales phylogeny as indicated by morphological and rDNA sequence data. Cryptogamic Botany 5: 82-97.

White, T. J., Bruns, T., Lee, S. \& Taylor, J. W. (1990) Amplification and direct sequencing of fungal ribosomal RNA genes for phylogenetics. In PCR Protocols, a Guide to Methods and Applications (M. A. Innis, D. H. Gelfan, J. J. Sninsky \& T. White, eds): 315-322. San Diego: Academic Press.

Yamamoto, Y. (1987) Tissue culture of lichens. In Tissue Cultures of Lichen and Bryophyte (Y. Yamada et al., eds): 14-25. Osaka: Nippon Paint Company.

Ziegenhagen, B., Guillemaut, P. \& Scholz, F. (1993) A procedure for mini-preparations of genomic DNA from needles of silver fir (Abies alba Mill.). Plant Molecular Biology Reports 11: $117-121$.

Accepted for publication 18 fuly 1999 